Jurnal Evaluasi Pendidikan, Vol. 2, No. 1, Maret 2011, 68-83

http://doi.org/10.21009/JEP

\title{
FREQUENCY OF FORMATIVE TEST SCORING AND THE STUDENT'S STUDY INDEPENDENCE
}

\author{
Supardi U. S. \\ Fakultas Teknik \& MIPA, Universitas Indraprasta PGRI \\ Tanjung Barat, Jagakarsa, Jakarta Selatan \\ supardi@unindra.ac.id \\ DOI: doi.org/JEP.021.06
}

\begin{abstract}
The objective of the study was to know the effects of interaction between formative assessment frequency and learning independence toward Calculus learning outcomes with controlling university students' prior capacity. Research using experimental methods with $2 \times 2$ treatment by level design, and can be concluded from the finding, that with controlling university students' prior capacity: (1) the group with high learning independence and was given formative assessment each subject matter got lower score on calculus learning outcomes than the group was given conventional formative assessment, (2) the group with low learning independence and was given formative assessment each subject matter got higher score calculus learning outcomes than the group was given conventional formative assessment, (3) the group was given formative assessment each subject matter and have high learning independence got lower score calculus learning outcomes than the have low learning independence, and (4) the group was given conventional formative assessment and have high learning independence got higher score calculus learning outcomes than the low learning independence. The result showed that there was interaction between formative assessment frequency and and learning independence toward Calculus learning outcomes with controlling university students' prior capacity. To improve the quality of Calculus learning outcomes, the lecturers were supposed to evaluate the university stuents' using formative assessment variously. It must be matched with level of the learning independence of university students'.
\end{abstract}

Keywords: formative assessment frequency, learning independence, Calculus learning outcomes, prior capacity in Calculus 


\title{
FREKUENSI PENILAIAN FOMATIF DAN KEMANDIRIAN BELAJAR
}

\author{
Supardi U. S. \\ Fakultas Teknik \& MIPA, Universitas Indraprasta PGRI \\ Tanjung Barat, Jagakarsa, Jakarta Selatan \\ supardi@unindra.ac.id
}

\begin{abstract}
Abstrak
Penelitian ini bertujuan mengetahui pengaruh interaksi antara frekuensi penilaian formatif dan kemandirian belajar terhadap hasil belajar kalkulus dengan mengontrol kemampuan awal mahasiswa. Penelitian menggunakan metode eksperimen dengan desain treatment by level $2 \times 2$, dan mendapatkan kesimpulan, bahwa dengan mengontrol kemampuan awal mahasiswa: (1) kelompok mahasiswa yang memiliki kemandirian belajar tinggi dan diberikan penilaian formatif per pokok bahasan memperoleh skor hasil belajar kalkulus lebih rendah dari pada yang diberikan penilaian formatif konvensional, (2) kelompok mahasiswa yang memiliki kemandirian belajar rendah dan diberikan penilaian formatif per pokok bahasan memperoleh skor hasil belajar kalkulus lebih tinggi dari pada yang diberikan penilaian formatif konvensional, (3) kelompok mahasiswa yang diberikan penilaian formatif per pokok bahasan dan memiliki kemandirian belajar tinggi memperoleh skor hasil belajar kalkulus lebih rendah dari pada yang memiliki kemandirian belajar rendah, dan (4) kelompok mahasiswa yang diberikan penilaian formatif konvensional dan memiliki kemandirian belajar tinggi memperoleh skor hasil belajar kalkulus lebih tinggi dari pada yang memiliki kemandirian belajar rendah.
\end{abstract}

Kata kunci: penilaian formatif, kemandirian belajar, hasil belajar Kalkulus, kemampuan awal mahasiswa

\section{PENDAHULUAN}

Salah satu pilar kebijakan strategis Kementerian Pendidikan Nasional dewasa ini yaitu peningkatan mutu, relevansi dan daya saing pendidikan. Sholeh (2005: 34) mengatakan peningkatan mutu pendidikan merupakan suatu langkah yang dilakukan secara terencana, yang mencakup dua strategi. Pertama, merupakan perencanaan jangka pendek untuk meningkatkan kemampuan intelektual peserta didik sebagai standar minimal untuk meraih tujuan pendidikan jangka panjang yang mengacu pada pengembangan manusia Indonesia seutuhnya. Kedua, adalah strategi jangka panjang yang mengarah ke tujuan pendidikan berlandasan luas, bermanfaat, nyata, dan bermakna dalam mempersiapkan peserta didik menghadapi tantangan masa depan. Walija (2007: 1) mengatakan, "lembaga-lembaga pendidikan yang tidak berkualitas lama kelamaan akan ditinggal-kan orang dan tersingkir dengan sendirinya. Dia tidak akan mampu bertahan. Berkualitas di sini mencakup berbagai bidang misalnya (1) berkualitas dalam bidang pembelajaran, (2) berkualitas dalam bidang 
pelayanan, dan (3) berkualitas dalam bidang sarana prasarana yang disediakan." Peningkatan mutu pendidikan dilakukan melalui upaya-upaya perbaikan proses pembelajaran dengan menggunakan berbagai metode pembelajaran dan penilaian formatif yang bervariasi.

Secara garis besar ilmu matematika terbagi atas beberapa bidang, antara lain: aritmatika, aljabar, geometri, trigonometri, kalkulus, probabilitas dan statistik, teori himpunan dan logika, teori bilangan, analisis sistem, dan teori ketidakberaturan. Kalkulus merupakan salah satu matakuliah yang ada pada Program Studi Pendidikan Matematika. Dalam bidang Teknik \& MIPA, kalkulus merupakan matakuliah yang sangat dibutuhkan sebagai landasan dalam mempelajari beberapa matakuliah lainnya.

Dalam pandangan dan persepsi mahasiswa masih banyak yang menganggap bahwa kalkulus merupakan pelajaran yang sulit dan tidak menarik. Dampak dari persepsi ini mengakibatkan sebagian mahasiswa tidak dapat fokus dan juga tidak mampu mendapatkan strategi belajar yang tepat, sehingga berakibat pada penguasaan konsep kalkulus yang rendah. Fenomena ini tergambar dari perolehan hasil belajar kalkulus mahasiswa yang relatif rendah jika dibandingkan dengan rerata hasil belajar matakuliah lainnya. Rendahnya penguasaan konsep kalkulus akan menghambat mahasiswa dalam pembelajaran matakuliah berikutnya, terutama pada matakuliah yang menjadikan kalkulus sebagai prasyarat, seperti: persamaan diferensial, fisika dasar, analisa real, analisa vektor, analisa kompleks, dan lain-lain. Buchori (2001: 121-122) mengatakan, "kalau kita betul-betul ingin meningkatkan kemampuan bangsa di bidang teknologi di masa depan, maka tidak boleh dibiarkan adanya anak-anak muda yang buta matematika." Hampir semua bidang ilmu rekayasa seperti teknik elektro, teknik mesin, teknik sipil, teknik industri, dan lain-lain dalam pengembangannya menggunakan konsep kalkulus. Demikian juga untuk bidangbidang ilmu eksakta lainnya seperti pertanian, kedokteran, farmasi dan lain-lain memerlukan konsep kalkulus dalam pengembangannya. Bahkan untuk bidangbidang ilmu sosial seperti ekonomi, psikologi, dan lainnya juga memerlukan konsep kalkulus.

Stewart (2001: 2) mengemukakan, "kalkulus mempelajari tentang konsep matematika yang terkait dengan diferensial dan integral suatu fungsi." Ronney (2009: 153) menyatakan, dasar-dasar dari kalkulus baik yang menyangkut diferensial maupun integral, keduanya telah ditemukan sekitar tahun 1670 secara terpisah oleh matematikawan berkebangsaan Inggris bernama Issac Newton dan polymath berkebangsaan Jerman bernama Gottfried Leibniz. Melalui konsep-konsep kalkulus permasalahan-permasalahan rumit dalam dunia nyata seperti pada bidang transportasi, astronomi, psikologi, kedokteran dan lainnya yang selama ini menjadi misteri menjadi terkuak dapat dipahami dan dipecahkan.

Hasil belajar kalkulus dapat diartikan sebagai perwujudan dari proses keberhasilan pembelajaran kalkulus yang dicerminkan dengan perubahan 
tingkah laku dalam bentuk kognitif, afektif maupun keterampilan seseorang setelah mendapatkan pengalaman belajar kalkulus. Dimyati dan Mudjiono (2006: 3) mengatakan bahwa, hasil belajar merupakan hasil dari suatu interaksi tindak belajar dan tindak mengajar. Mahasiswa bertindak belajar, artinya mengalami proses dan peningkatan kemampuan mentalnya.

Untuk mengetahui seberapa besar kematangan atau peningkatan kecakapan baru seseorang sebagai wujud dari hasil belajar perlu dilakukan pengukuran dan penilaian. Zainul dan Nasution (2005: 9) menyatakan, "penilaian hasil belajar baru dapat dilakukan dengan baik dan benar bila menggunakan informasi yang diperoleh melalui pengukuran hasil belajar."

Hasil belajar kalkulus terwujud dari kecakapan seseorang dalam menyelesaikan problema (masalah) yang terkait dengan konsep-konsep kalkulus. Menurut Shaffat (2009: 6-7), tujuan belajar sangat terkait dengan kemampuan kognitif, afektif dan psikomotorik. Pencapaian transfer belajar merupakan tujuan utama pengajaran kalkulus. Tingkat kualitas hasil belajar kalkulus sangat dipengaruhi adanya proses transfer belajar. Pencapaian transfer belajar kalkulus dapat diamati melalui struktur kognitif yang telah dimiliki mahasiswa tentang konsep dan teorema yang dipelajari.

Peningkatan kualitas hasil belajar kalkulus, harus diimbangi dengan kompetensi para dosen, yaitu kemampuan untuk mengajar dan melakukan inovasi penilaian formatif. Zainul dan Nasution (2005: 9) mengatakan, "secara garis besar penilaian dapat dibagi menjadi dua, yaitu penilaian formatif dan penilaian sumatif." Penilaian formatif dilakukan untuk memantau sejauh mana suatu proses pendidikan telah berjalan sebagaimana yang direncanakan. Penilaian hasil belajar mahasiswa yang dilakukan oleh dosen selain untuk memantau proses, kemajuan dan perkembangan hasil belajar, juga sebagai umpan balik bagi dosen agar dapat menyempurnakan program pembelajaran. Susetyo (2008) mengatakan, penilaian formatif umumnya digunakan untuk mengukur kemampuan peserta didik terutama dalam bidang kognitif. Ditinjau dari cakupan materi ajar biasanya penilaian formatif dilakukan setelah selesai satu pokok bahasan atau setelah beberapa pokok bahasan sekaligus.

Gage and Berliner (1984: 723) mengemukakan, pendidik dan peserta didik keduanya membutuhkan informasi umpan balik tentang bagaimana mereka bekerja sebagai pengajar dan pembelajar. Melalui penilaian formatif dapat diperoleh umpan balik yang dibutuhkan. Tujuan penilaian formatif adalah untuk membantu mahasiswa dan dosen dalam proses pembelajaran sehingga mahasiswa mempunyai penguasaan yang tuntas (mastery). Black and Wiliam (2011) mengemukakan, secara umum digunakan istilah 'penilaian' untuk menyebut semua kegiatan yang dilakukan oleh pendidik, yang memberikan informasi umpan balik untuk memodifikasi proses pembelajaran. Penilaian semacam ini merupakan penilaian formatif apabila informasi yang diperoleh betul-betul digunakan untuk perbaikan pengajaran. 
Esensi kemandirian belajar yaitu adanya aktivitas belajar yang diatur oleh diri sendiri, kesadaran sendiri, dan bersifat mandiri. Secara konseptual, kemandirian belajar berbeda dengan belajar mandiri. Brookfield (1986: 48) mengatakan, belajar mandiri menekankan pada pengaturan kebutuhan sendiri atau sifat kemandirian belajar. Selain pengelolaan belajar mandiri, mengatur kebutuhan belajar sendiri, dan belajar atas kesadaran sendiri, dalam kemandirian belajar ju-ga terjadi self teaching. Self directed artinya bahwa mahasiswa belajar dengan pengendalian diri, diatur sendiri atau dikelola sendiri serta bersifat mandiri. Autonomous learning berarti bahwa mahasiswa mampu memilih dan mene-tapkan batas materi pelajaran yang perlu dipelajari sesuai dengan kebutuhannya. Voluntary learning, artinya bahwa mahasiswa cenderung belajar dengan tidak ada paksaan, melainkan atas inisiatif dan kesadaran sendiri. Self teaching artinya bahwa mahasiswa dapat mengajar diri sendiri melalui pengalaman, baik penga-laman keberhasilan maupun kegagalan. Prawiradilaga dan Siregar (2008: 190) menyatakan, model belajar mandiri sangat bermanfaat, karena dianggap luwes, tidak mengikat, serta melatih kemandirian mahasiswa agar tidak bergantung pada kehadiran atau penjelasan materi dari dosen. Kemandirian belajar dapat dibangun melalui pengembangan model-model belajar mandiri. Model belajar mandiri merupakan sarana melatih kemandirian belajar. Kemandirian belajar dapat terwujud, apabila mahasiswa dapat memiliki motivasi belajar tinggi dan memiliki keyakinan atau percaya diri yang tinggi.

Hasil belajar kalkulus juga dipengaruhi oleh kemampuan awal mahasiswa. Mahasiswa yang memiliki kemampuan awal baik, akan mampu mengikuti proses pembelajaran di kelas dengan baik, sehingga hasil belajarnya secara keseluruhan akan baik pula. Kemampuan awal merupakan kecakapan atau potensi (ability) yang ada dalam jiwa seseorang. Djaali (2008: 1) mengemukakan, pada dasarnya jiwa manusia dibedakan menjadi dua aspek, yakni aspek kemampuan (ability) dan aspek kepribadian (personality). Dalam konteks belajar, maka ada kemampuan yang dimiliki mahasiswa sebelum belajar dan ada pula kemampuan pasca belajar. Totalitas kemampuan yang dimiliki mahasiswa pada saat akan memasuki kegiatan (sebelum) belajar disebut kemampuan awal. Dewey (2009: 64) mengatakan, pembelajaran harus bertolak dari pengalaman dan kemampuan yang telah dimiliki peserta didik sebelum masa belajar sebagai landasan agar pengalaman dan kemampuannya berkembang pada pelajaran berikutnya. Pidarta (2007: 229), menyatakan "kesiapan belajar adalah kemampuan seseorang untuk mendapat-kan keuntungan dari pengalaman yang ia temukan. Sementara itu kesiapan kognisi bertalian dengan pengetahuan, pikiran dan kualitas berpikir seseorang dalam menghadapi situasi belajar yang baru." Kondisi kemampuan awal mahasiswa dapat dijadikan sebagai prasyarat untuk mengikuti kegiatan belajar suatu mata-kuliah tertentu. Hal ini dikarenakan adanya keterpautan yang kuat antara kemampuan awal dengan materi pelajaran baru yang akan dipelajari. 
Penelitian ini bertujuan untuk mengetahui pengaruh frekuensi penilaian fomatif dan kemandirian belajar terhadap hasil belajar kalkulus dengan mengontrol kemampuan awal mahasiswa.

\section{METODE PENELITIAN}

Penelitian ini menggunakan metode eksperimen. Penelitian ini menempatkan hasil belajar kalkulus dengan skala numerik sebagai variabel terikat (criterion variable), frekuensi penilaian formatif (treatment variable) sebagai variabel bebas pertama, kemandirian belajar dengan skala numerik yang dikelompokkan secara bertingkat menjadi kategori tinggi dan rendah sebagai variabel bebas atribut (variabel bebas kedua), dan kemampuan awal kalkulus dengan skala numerik sebagai variabel bebas kovariat. Sebelum dilakukan perlakuan, terlebih dulu dilakukan pengukuran kemampuan awal kalkulus mahasiswa. Penelitian menggunakan desain treatment by level.

Populasi target penelitian ini adalah seluruh mahasiswa peserta kuliah kalkulus pada Universitas Indraprasta PGRI (UNINDRA). Sampel penelitian yang diberi perlakuan yaitu mahasiswa Program Studi Pendidikan Matematika semester IV. Jumlah sampel penelitian sebanyak 80 orang dengan distribusi setiap kelompok penelitian 20 orang. Teknik sampling dilakukan dengan multi stage sampling.

Instrumen tes menggunakan tes uraian sebanyak 17 butir soal dengan koefisien reliabilitas sebesar 0,93. Teknik analisis data meliputi analisis deskriptif, uji persyaratan analisis dan analisis inferensial Ankova. Sebelum dilakukan analisis inferensial untuk pengujian hipotesis penelitian terlebih dahulu dilakukan uji prasyarat analisis yang meliputi: (1) uji normalitas, (2) uji homogenitas, (3) uji linearitas, (4) uji keberartian pengaruh kovariat terhadap variabel terikat, dan (5) uji kesejajaran garis regresi.

\section{HASIL PENELITIAN}

Hasil pengujian persyaratan analisis telah menunjukkan kriteria yang memenuhi persyaratan untuk melakukan Ankova. Analisis inferensial untuk menguji hipotesis penelitian diperoleh hasil seperti berikut:

\section{Pengujian Hipotesis tentang Pengaruh Frekuensi Penilaian Formatif terhadap Hasil Belajar Kalkulus dengan Mengontrol Kemampuan Awal Mahasiswa}

Hasil analisis untuk pengujian hipotesis seperti dalam tabel 1 . baris $A$, diperoleh nilai $F_{\text {hitung }}=7,269$ dengan nilai sig. $=0,009<0,05$, maka disimpulkan terdapat perbedaan hasil belajar kalkulus yang signifikan menurut faktor frekuensi penilaian formatif dengan mengontrol kemampuan awal. Fenomena ini menunjukkan terdapat pengaruh frekuensi penilaian formatif terhadap hasil belajar kalkulus dengan mengontrol kemampuan awal. Penelitian berhasil 
menemukan bahwa hasil belajar kalkulus mahasiswa yang diberikan penilaian formatif per pokok bahasan lebih tinggi dari pada penilaian formatif konvensional. Kesimpulan ini didukung dengan perolehan rerata hasil belajar kalkulus mahasiswa yang diberikan penilaian formatif per pokok bahasan sebesar 80,05 dan yang diberikan penilaian formatif konvensional sebesar 74,22.

Tabel 1. Hasil Analisis untuk Pengujian Hipotesis Perbedaan $Y$ menurut Faktor $A$ dengan mengontrol $X$

\begin{tabular}{lrrrrl}
\hline \multicolumn{1}{c}{ Sumber Varian } & \multicolumn{1}{c}{ JKres } & db & \multicolumn{1}{c}{ RJK } & \multicolumn{1}{c}{ F } & \multicolumn{1}{c}{ Sig. } \\
\hline Model Dikoreksi & $1.942,912$ & 2 & 971,456 & 16,452 & 0,000 \\
Intercept & $16.001,336$ & 1 & $16.001,336$ & 270,996 & 0,000 \\
$X$ & $1.264,300$ & 1 & $1.264,300$ & 21,412 & 0,000 \\
$A$ & 429,231 & 1 & 429,231 & 7,269 & 0,009 \\
Kesalahan & $4.546,575$ & 77 & 59,046 & & \\
Total & $482.505,000$ & 80 & & & \\
Total Dikoreksi & $6.489,487$ & 79 & & & \\
\hline
\end{tabular}

Sumber: Data Primer diolah dengan SPSS versi 17.0

Pengujian Hipotesis tentang Pengaruh Kemandirian Belajar terhadap Hasil Belajar Kalkulus dengan Mengontrol Kemampuan Awal Mahasiswa

Hasil analisis untuk pengujian hipotesis seperti dalam tabel 2. baris $B$, diperoleh nilai $F_{\text {hitung }}=6,868$ dengan nilai sig. $=0,011<0,05$; maka disimpulkan terdapat perbedaan hasil belajar kalkulus yang signifikan menurut faktor kemandirian belajar dengan mengontrol kemampuan awal. Fenomena ini menunjukkan terdapat pengaruh kemandirian belajar yang signifikan terhadap hasil belajar kalkulus dengan mengontrol kemampuan awal. Penelitian menemukan bahwa rerata hasil belajar kalkulus mahasiswa yang memiliki kemandirian belajar tinggi lebih tinggi dari pada yang memiliki kemandirian belajar rendah. Perolehan rerata hasil belajar kalkulus mahasiswa yang memiliki kemandirian belajar tinggi sebesar 78,90 berbeda dengan yang memiliki kemandirian belajar rendah sebesar 75,38.

Tabel 2. Hasil Analisis untuk Pengujian Hipotesis Perbedaan Y menurut Faktor B dengan Mengontrol X

\begin{tabular}{lccccc}
\hline \multicolumn{1}{c}{ Sumber Varian } & JK $_{\text {res }}$ & Db & RJK & $\mathbf{F}$ & Sig. \\
\hline Model Dikoreksi & $1.921,146$ & 2 & 960,573 & 16,191 & 0,000 \\
Intercept & $14.869,392$ & 1 & $14.869,392$ & 250,626 & 0,000 \\
$X$ & $1.672,633$ & 1 & $1.672,633$ & 28,192 & 0,000 \\
$B$ & 407,465 & 1 & 407,465 & 6,868 & 0,011 \\
Kesalahan & $4.568,342$ & 77 & 59,329 & & \\
Total & $482.505,000$ & 80 & & & \\
Total Dikoreksi & $6.489,487$ & 79 & & & \\
\hline
\end{tabular}

Sumber: Data Primer diolah dengan SPSS versi 17.0 
Pengujian Hipotesis tentang Pengaruh Interaksi antara Frekuensi Penilaian Formatif dan Kemandirian Belajar terhadap Hasil Belajar Kalkulus dengan Mengontrol Kemampuan Awal Mahasiswa

Hasil analisis untuk pengujian hipotesis seperti dalam Tabel 3 baris $A^{*} B$, diperoleh nilai $F_{\text {hitung }}=38,210$ dengan nilai sig. $=0,000<0,05$; maka disimpulkan terdapat pengaruh interaksi antara frekuensi penilaian formatif dan kemandirian belajar terhadap hasil belajar kalkulus dengan mengontrol kemampuan awal mahasiswa. Dengan mengontrol kemampuan awal mahasiswa ditemukan bahwa, pada kelompok mahasiswa yang memiliki kemandirian belajar tinggi lebih efektif diberikan penilaian formatif konvensional (keseluruhan) dari pada diberikan penilaian formatif per pokok bahasan. Sementara, untuk kelompok mahasiswa yang memiliki kemandirian belajar rendah lebih efektif diberikan penilaian formatif per pokok bahasan daripada diberikan penilaian formatif konvensional, setelah mengontrol pengaruh kemampuan awal mahasiswa.

Tabel 3. Hasil Analisis untuk Pengujian Hipotesis Pengaruh Interaksi $A * B$ terhadap $Y$ dengan Mengontrol $\mathrm{X}$

\begin{tabular}{lccccc}
\hline \multicolumn{1}{c}{ Sumber Varian } & JK $_{\text {res }}$ & $\mathbf{d b}$ & $\mathbf{R J K}$ & $\mathbf{F}$ & Sig. \\
\hline Model Dikoreksi & $3.738,668$ & 4 & 934,667 & 25,483 & 0,000 \\
Intercept & $16.489,877$ & 1 & $16.489,877$ & 449,590 & 0,000 \\
$X$ & 380,531 & 1 & 380,531 & 10,375 & 0,002 \\
$A$ & 514,717 & 1 & 514,717 & 14,034 & 0,000 \\
$B$ & 324,673 & 1 & 324,673 & 8,852 & 0,004 \\
$A^{*} B$ & $1.401,464$ & 1 & $1.401,464$ & 38,210 & 0,000 \\
Kesalahan & $2.750,819$ & 75 & 36,678 & & \\
Total & $482.505,000$ & 80 & & & \\
Total Dikoreksi & $6.489,487$ & 79 & & & \\
\hline
\end{tabular}

Sumber: Data Primer diolah dengan SPSS versi 17.0

\section{Menguji Perbedaan Rerata $Y$ antara Tingkat Faktor $A$ untuk setiap Tingkat Faktor $B$ dengan mengontrol $X$}

Dari tabel 4, dapat diuji hipotesis simple effect sebagai berikut.

a) Hipotesis tentang perbedaan hasil belajar kalkulus antara mahasiswa yang diberikan penilaian formatif per pokok bahasan dan penilaian formatif konvensional dengan mengontrol kemampuan awal, khusus pada mereka yang memiliki kemandirian belajar tinggi

Pada baris $\left[(A=1)^{*}(B=1)\right]$ di atas, diperoleh nilai $t_{\text {hitung }}=-2,046$ dengan nilai sig. $=0,044<0,05$; sehingga $H_{0}$ ditolak dan disimpulkan bahwa dengan mengontrol kemampuan awal, pada kelompok mahasiswa yang memiliki kemandirian belajar tinggi dan diberikan penilaian formatif per pokok bahasan lebih rendah dari pada yang diberikan penilaian formatif konvensional. Kesimpulan ini didukung pula dengan perolehan rerata hasil belajar kalkulus mahasiswa yang memiliki kemandirian belajar tinggi dan 
diberikan penilaian formatif per pokok bahasan sebesar 76,30 lebih rendah dari pada yang diberikan penilaian formatif konvensional sebesar 81,50.

b) Hipotesis tentang perbedaan hasil belajar kalkulus antara mahasiswa yang diberikan penilaian formatif per pokok bahasan dan penilaian formatif konvensional dengan mengontrol kemampuan awal, khusus pada mereka yang memiliki kemandirian belajar rendah.

Pada baris $[(A=1) *(B=2)]$ di atas, diperoleh nilai $t_{\text {hitung }}=6,869$ dengan nilai sig. $=0,000<\alpha=0,05$; sehingga $H_{0}$ ditolak dan disimpulkan bahwa dengan mengontrol kemampuan awal, pada kelompok mahasiswa yang memiliki kemandirian belajar rendah dan diberikan penilaian formatif per pokok bahasan lebih tinggi dari pada yang diberikan penilaian formatif konvensional. Kesimpulan ini didukung pula dengan perolehan rerata hasil belajar kalkulus mahasiswa yang memiliki kemandirian belajar rendah dan diberikan penilaian formatif per pokok bahasan sebesar 83,80 lebih tinggi dari pada yang diberikan penilaian formatif konvensional sebesar 66,95.

Tabel 4. Estimasi Parameter untuk Pengujian perbedaan Rerata $Y$ antara Tingkat Faktor A untuk Setiap Tingkat Faktor B dengan Mengontrol X

\begin{tabular}{lccccc}
\hline \multicolumn{1}{c}{ Parameter } & Simbol & B & Std. Error & t & Sig. \\
\hline Intercept & $B_{0}$ & 58,008 & 3,089 & 18,780 & 0,000 \\
$X$ & $\delta_{0}$ & 0,155 & 0,048 & 3,221 & 0,002 \\
{$[B=1]$} & $B_{1}$ & 13,187 & 1,961 & 6,724 & 0,000 \\
{$[B=2]$} & - & 0 &. &. &. \\
{$[A=1]^{*}[B=1]$} & $B_{2}$ & $-3,992$ & 1,952 & $-2,046$ & 0,044 \\
{$[A=1]^{*}[B=2]$} & $B_{3}$ & 14,264 & 2,077 & 6,869 & 0,000 \\
{$[A=2]^{*}[B=1]$} & - & 0 &. &. &. \\
{$[A=2]^{*}[B=2]$} & - & 0 &. &. &. \\
\hline
\end{tabular}

Sumber: Data Primer diolah dengan SPSS versi 17.0

\section{Menguji Perbedaan Rerata $Y$ antara Tingkat Faktor B untuk setiap Tingkat Faktor A dengan mengontrol $X$}

Dari tabel 5 dapat diuji hipotesis simple effect sebagai berikut.

a) Hipotesis tentang perbedaan hasil belajar kalkulus antara mahasiswa yang memiliki kemandirian belajar tinggi dan kemandirian belajar rendah dengan mengontrol kemampuan awal, khusus pada mereka yang diberikan penilaian formatif per pokok bahasan

Pada baris $\left[(A=1)^{*}(B=1)\right]$ di atas, diperoleh nilai $\mathrm{t}=-2,462$ dengan nilai sig. $=$ $0,016<0,05$; sehingga $\mathrm{H}_{0}$ ditolak dan disimpulkan bahwa dengan mengontrol kemampuan awal, pada kelompok mahasiswa yang diberikan penilaian formatif per pokok bahasan dan memiliki kemandirian belajar tinggi lebih rendah dari pada yang memiliki kemandirian belajar rendah. Kesimpulan ini didukung pula dengan perolehan rerata hasil belajar kalkulus kelompok yang diberikan penilaian formatif per pokok bahasan dan memiliki kemandirian 
belajar tinggi sebesar 76,30 lebih rendah dari pada yang memiliki kemandirian belajar rendah sebesar 83,80. Fenomena ini menunjukkan, pemberian penilaian formatif per pokok bahasan lebih cocok untuk mereka yang memiliki kemandirian belajar rendah, dibandingkan dengan mereka yang memiliki kemandirian belajar tinggi.

b) Hipotesis tentang perbedaan hasil belajar kalkulus antara mahasiswa yang memiliki kemandirian belajar tinggi dan kemandirian belajar rendah dengan mengontrol kemampuan awal, khusus pada mereka yang diberikan penilaian formatif per pokok bahasan.

Pada baris $\left[(A=2)^{*}(B=1)\right]$ di atas, diperoleh nilai $\mathrm{t}=6,724$ dengan nilai sig. $=$ $0,000<0,05$; sehingga $\mathrm{H}_{0}$ ditolak dan disimpulkan bahwa dengan mengontrol kemampuan awal, pada kelompok mahasiswa yang diberikan penilaian formatif konvensional dan memiliki kemandirian belajar tinggi lebih tinggi secara signifikan dari pada yang memiliki kemandirian belajar rendah. Kesimpulan ini didukung pula dengan perolehan rerata hasil belajar kalkulus mahasiswa yang diberikan penilaian formatif konvensional dan memiliki kemandirian belajar tinggi sebesar 81,50 lebih tinggi dari pada yang memiliki kemandirian belajar rendah sebesar 66,95. Fenomena tersebut menunjukkan, bahwa pemberian penilaian formatif konvensional lebih cocok untuk mahasiswa yang memiliki kemandirian belajar tinggi, dibandingkan yang memiliki kemandirian belajar rendah.

Tabel 5. Estimasi Parameter untuk Pengujian Perbedaan Rerata $Y$ antara Tingkat Faktor $B$ untuk Setiap Tingkat Faktor $A$ dengan Mengontrol $X$

\begin{tabular}{lccccc}
\hline \multicolumn{1}{c}{ Parameter } & Simbol & B & Std. Error & t & Sig. \\
\hline Intercept & $B_{0}$ & 58,008 & 3,089 & 18,780 & 0,000 \\
$X$ & $\delta_{0}$ & 0,155 & 0,048 & 3,221 & 0,002 \\
{$[A=1]$} & $B_{1}$ & 14,264 & 2,077 & 6,869 & 0,000 \\
{$[A=2]$} & - & 0 &. &. &. \\
{$[A=1]^{*}[B=1]$} & $B_{2}$ & $-5,069$ & 2,058 & $-2,462$ & 0,016 \\
{$[A=1]^{*}[B=2]$} & - & 0 &. &. &. \\
{$[A=2]^{*}[B=1]$} & $B_{3}$ & 13,187 & 1,961 & 6,724 & 0,000 \\
{$[A=2]^{*}[B=2]$} & - & 0 &. &. &. \\
\hline
\end{tabular}

Sumber: Data Primer diolah dengan SPSS versi 17.0

\section{PEMBAHASAN}

Dalam penelitian ini yang dimaksud hasil belajar kalkulus yaitu hasil belajar kalkulus integral. Kalkulus integral merupakan matakuliah yang menuntut pemahaman yang mendalam secara konseptual. Kalkulus integral merupakan kelanjutan dari matakuliah kalkulus diferensial. Penguasaan konsep turunan sebagai materi utama dalam kalkulus diferensial akan sangat berpengaruh 
terhadap hasil belajar kalkulus integral. Penguasaan konsep turunan merupakan pengetahuan prasyarat yang harus dimiliki oleh mahasiswa sebelum mempelajari matakuliah kalkulus integral. Oleh karenanya, pengaruh dari penguasaan pada konsep prasyarat tersebut harus dikontrol agar tidak menimbulkan kerancuan atau bias dalam penarikan kesimpulan penelitian. Penguasaan terhadap konsep pengetahuan prasyarat tersebut dalam penelitian ini disebut dengan kemampuan awal kalkulus mahasiswa. Kalkulus sebagai bagian dari matematika selalu berkenaan dengan ide-ide atau konsep-konsep abstrak yang tersusun secara hierarki dengan menggunakan penalaran deduktif. Pengajaran kalkulus di perguruan tinggi tersusun berdasarkan materi-materi yang satu dengan lainnya saling berhubungan, artinya penguasaan terhadap materi yang satu akan mempengaruhi penguasaan terhadap materi berikutnya. Mengingat banyaknya cakupan yang perlu dibahas dalam matakuliah kalkulus, maka untuk mendapatkan hasil terbaik setiap mahasiswa harus belajar dan dinilai secara teratur dan sistematik. Latihan-latihan soal terstruktur dan sesuai pokok bahasan yang dipelajari akan menjadi langkah terbaik untuk mendapatkan hasil belajar yang optimal dalam mata kuliah ini.

Pemberian frekuensi penilaian formatif dimaksudkan untuk memberikan gambaran tentang pengaruh pelaksanaan penilaian formatif terhadap hasil belajar kalkulus mahasiswa. Frekuensi penilaian formatif yang dimaksud meliputi: (1) frekuensi penilaian formatif per pokok bahasan, yaitu kekerapan penilaian formatif hasil belajar mahasiswa yang dilakukan setelah selesai setiap pokok bahasan, dan (2) frekuensi penilaian formatif konvensional, yaitu kekerapan penilaian formatif hasil belajar mahasiswa yang dilakukan seperti yang berlangsung selama ini, yakni dilakukan setelah materi secara keseluruhan selesai.

Black and Wiliam (1998) menyatakan, bahwa inovasi penilaian formatif merupakan salah satu aspek yang menentukan kualitas proses dan hasil pembelajaran di dalam kelas. Inovasi penilaian formatif per pokok bahasan memberi kesempatan mahasiswa untuk dinilai tingkat pemahamannya dalam belajar kalkulus yang dilakukan sedikit demi sedikit secara bertahap tetapi sering. Kegiatan penilaian formatif semacam ini diharapkan dapat memudahkan mahasiswa dalam mempelajari materi pembelajaran penilain formatif per pokok bahasan memberi kesempatan pada mahasiswa untuk langsung mengikuti tes/penilaian tidak lama setelah materi diajarkan, sehingga diharapkan materi tersebut masih terekam dengan baik dalam otak. Dalam penilaian formatif per pokok bahasan, mahasiswa dapat segera diketahui ketuntasan belajarnya untuk setiap bagian materi yang telah dipelajarinya, sehingga apabila belum dicapai tingkat ketuntasan belajarnya dapat segera dilakukan remedial. Sementara, penilaian formatif konvensional dilakukan setelah seluruh materi kalkulus yang ditetapkan dalam kurikulum selesai diajarkan semuanya. Kondisi ini memberi kesempatan mahasiswa untuk belajar sekaligus dalam menghadapi tes untuk penilaian formatif. Materi yang harus dipelajari sangat banyak, dan mungkin 
sebagian sudah agak terlupakan karena waktu belajarnya sudah berlalu cukup lama. Fenomena ini akan dirasakan menjadi beban dan kesulitan tersendiri terutama untuk mahasiswa yang inisiatif belajarnya kurang. Dengan penilaian formatif konvensional, tingkat ketuntasan belajar mahasiswa baru diketahui setelah semua materi kalkulus selesai diajarkan. Setelah dilakukan penilaian, kemudian dosen menganasilis materi mana yang sudah dikuasai dan materi mana yang belum tuntas untuk setiap mahasiswa. Berdasarkan hasil analisis tersebut selanjutnya dosen melakukan remedial terhadap materi yang belum dikuasai oleh mahasiswa.

Secara keseluruhan pemberian penilaian formatif per pokok bahasan akan lebih efektif dari pada pemberian penilaian formatif konvensional dalam proses pembelajaran kalkulus. Hal ini sesuai dengan yang diungkapkan oleh Black dan Wiliam (1998) yang menyatakan, hasil penelitian pada mahasiswa di beberapa negara menunjukkan bahwa dengan melakukan inovasi penilaian formatif yang lebih sering memberikan dampak pada hasil belajar yang signifikan. Kondisi inilah yang menyebabkan hasil belajar kalkulus mahasiswa yang diberikan penilaian formatif per pokok bahasan lebih tinggi dari pada yang diberikan penilaian formatif konvensional.

Kemandirian belajar merupakan suatu perwujudan dari indikator tanggung jawab seseorang dalam keberhasilan belajarnya. Seseorang yang memiliki kemandirian belajar tinggi biasanya akan memiliki pandangan jauh ke depan mengenai rancangan masa depan dan cita-cita yang ingin diraihnya. Ini berarti bahwa kemandirian merupakan sebuah sikap dan kebutuhan psikologis seseorang yang harus dikembangkan dan dilatih secara kontinu oleh seluruh peserta didik. Sebagai seorang intelektual muda, mahasiswa harus memiliki kemandirian dalam belajar. Mahasiswa sebagai tokoh perubahan harus dapat memberikan contoh dan bertanggung jawab terhadap keberhasilan belajarnya. Akan tetapi, kemandirian belajar ini ternyata belum diresapi oleh seluruh mahasiswa, sehingga terlihat dari hasil penelitian bahwa masih ada mahasiswa yang memiliki kemandirian belajar rendah.

Model belajar di perguruan tinggi berbeda dengan di tingkat pendidikan dasar maupun menengah. Belajar di perguruan tinggi, terkadang didapati dosen yang memiliki kesibukan luar biasa, sehingga berdampak pada kualitas dan kuantitas kehadiran kuliah di kelas. Oleh karena itu, mahasiswa harus berupaya menambah materi pelajaran yang diterima, sehingga dapat mencapai kompetensi yang dipersyaratkan dalam matakuliah yang bersangkutan dengan cara belajar mandiri. Dalam belajar kalkulus sebagai salah satu materi kuliah di program studi pendidikan matematika, menuntut inisiatif mahasiswa untuk mencari sumbersumber bahan belajar tambahan dan latihan guna mengembangkan kompetensinya. Tanpa upaya ini, mahasiswa akan tertinggal dalam penguasaan dan pemahaman materi kuliah. Mahasiswa yang memiliki kemandirian belajar tinggi akan mampu mengembangkan kompetensinya secara optimal. Melalui karakter kemandirian belajar yang dimilikinya, mahasiswa 
Jurnal Evaluasi Pendidikan, Vol. 2, No. 1, Maret 2011, 68-83

http://doi.org/10.21009/JEP

memiliki inisiatif dan bertanggung jawab untuk berupaya mencari dan menemukan materi atau bahan belajar tambahan yang diperlukan.

Model pengaruh interaksi dapat dijelaskan sebagai berikut: (1) pada mahasiswa yang memiliki kemandirian belajar tinggi lebih cocok jika mereka diberikan penilaian formatif konvensional, (2) pada mahasiswa yang memiliki kemandirian belajar rendah lebih cocok jika mereka diberikan penilaian per pokok bahasan. Hal tersebut terjadi, karena dimungkinkan bagi mahasiswa yang memiliki kemandirian belajar tinggi, ada kecenderungan mereka memiliki tingkat kreativitas yang tinggi. Mahasiswa yang memiliki kreativitas yang tinggi cenderung menikmati proses pembelajaran. Penilaian formatif konvensional akan memberi tantangan tersendiri bagi mereka yang memiliki kemandirian belajar tinggi, sehingga mereka akan tertarik belajar dan mendapatkan hasil belajar yang optimal. Sementara bagi mahasiswa yang memiliki kemandirian belajar rendah, akan cenderung melakukan kegiatan belajar sesuai perintah atau petunjuk dosen. Ada kecenderungan mereka kurang kreatif dan inisiatif dalam belajar. Oleh karenanya, melalui penilaian formatif yang lebih intensif (sering) secara tidak langsung menyuruh mahasiswa untuk belajar. Untuk ini, maka pemberian penilaian formatif per pokok bahasan akan dapat mengoptimalkan hasil belajar kalkulus mahasiswa yang memiliki kemandirian belajar rendah.

Pemberian penilaian formatif per pokok bahasan lebih cocok untuk mereka yang memiliki kemandirian belajar rendah dibandingkan pemberian penilaian formatif konvensional. Penilaian formatif per pokok bahasan merupakan suatu bentuk penilaian yang menekankan pengujian pemahaman mahasiswa terhadap materi pelajaran secara bertahap, bagian per bagian, dan dilakukan dengan frekuensi yang lebih sering. Penilaian formatif per pokok bahasan menuntun mahasiswa untuk menguasai seluruh materi dengan cara bertahap, dicicil, dan bagian per bagian. Selain itu penilaian formatif ini juga dengan sifatnya yang lebih intensif sekaligus juga dapat berfungsi sebagai stimulan bagi mahasiswa untuk belajar. Kondisi seperti ini sangat cocok bagi mereka yang memiliki tingkat kemandirian belajar rendah.

Dalam penilaian formatif per pokok bahasan terjadi kegiatan penilaian yang menekankan pengujian pemahaman mahasiswa terhadap materi pelajaran secara bertahap, bagian per bagian, dicicil, dan dilakukan dengan frekuensi yang lebih sering. Selain itu penilaian formatif ini juga dengan sifatnya yang lebih intensif (sering) sekaligus juga dapat berfungsi sebagai stimulan bagi mahasiswa untuk belajar. Kondisi ini membuat mahasiswa yang memilikik kemandirian belajar rendah akan merasa sangat terbantu dan termotivasi jika diberikan penilaian formatif per pokok bahasan. Dengan pola penilaian formatif per pokok bahasan akan memudahkan mereka yang memiliki kamandirian belajar rendah dalam mempelajari materi yang dilakukan sedikit demi sedikit. Dengan demikian, dapat dipahami bahwa pemberian frekuensi penilaian formatif per pokok bahasan lebih cocok untuk mahasiswa yang memiliki kemandirian belajar rendah. 
Dalam penilaian formatif konvensional terjadi kegiatan penilaian yang menekankan pengujian pemahaman mahasiswa terhadap materi pelajaran sekaligus secara menyeluruh dan tidak bertele-tele. Penilaian formatif konvensional memberi kesempatan pada mahasiswa untuk mengatur belajar dengan gaya dan kemauannya sendiri. Selain itu, dengan sifatnya yang simpel dan menyeluruh maka penilaian formatif konvensional sekaligus berfungsi untuk memberi peluang pada mahasiswa berkreasi dalam belajar. Mahasiswa yang memiliki Kemandirian belajar tinggi membutuhkan adanya ruang yang bebas dalam mendesain cara belajarnya sendiri. Mahasiswa yang memiliki kemandirian belajar tinggi berkecenderungan mempunyai tingkat kreativitas dan inisiatif yang tinggi dalam belajar. Hal ini sangat berbeda dengan mereka yang memiliki kemandirian belajar rendah. Umumnya bagi mahasiswa yang memiliki kemandirian belajar rendah lebih menyukai suatu bentuk tugas yang diarahkan secara lebih rinci dan terperinci. Dalam kegiatan belajar, mereka lebih banyak bergantung pada dorongan atau permintaan pihak lain, seperti dosen, orang tua maupun teman. Dengan demikian, dapat dipahami bahwa pemberian penilaian formatif konvensional lebih cocok untuk mahasiswa yang memiliki kemandirian belajar tinggi.

\section{SIMPULAN}

Berdasarkan temuan dengan mempertimbangkan keterbatasan penelitian, disimpulkan seperti berikut: (1) terdapat pengaruh frekuensi penilaian formatif terhadap hasil belajar kalkulus dengan mengontrol kemampuan awal mahasiswa; (2) terdapat pengaruh kemandirian belajar terhadap hasil belajar kalkulus dengan mengontrol kemampuan awal mahasiswa; (3) terdapat pengaruh interaksi antara frekuensi penilaian formatif dan kemandirian belajar terhadap hasil belajar kalkulus dengan mengontrol kemampuan awal mahasiswa.

Pola pengaruh interaksi yang terjadi adalah dengan mengontrol pengaruh kemampuan awal: (a) pada mahasiswa yang memiliki kemandirian belajar tinggi, hasil belajar kalkulus yang diberikan penilaian formatif per pokok bahasan lebih rendah dari penilaian formatif konvensional, (b) pada mahasiswa yang memiliki kemandirian belajar rendah, hasil belajar kalkulus yang diberikan penilaian formatif per pokok bahasan lebih tinggi dari pada penilaian formatif konvensional, (c) pada mahasiswa yang diberikan penilaian formatif per pokok bahasan, hasil belajar kalkulus yang memiliki kemandirian belajar tinggi lebih rendah dari pada kemandirian belajar rendah, dan (d) pada mahasiswa yang diberikan penilaian formatif konvensional, hasil belajar kalkulus yang memiliki kemandirian belajar tinggi lebih tinggi dari pada kemandirian belajar rendah. 
Jurnal Evaluasi Pendidikan, Vol. 2, No. 1, Maret 2011, 68-83

http://doi.org/10.21009/JEP

\section{DAFTAR PUSTAKA}

Black, Paul dan Dylan Wiliam. (1998). "Inside the Black Box: Raising Standards Through Classroom Assessment". Phi Delta Kappa International Journal. http://blog.discoveryeducation.com/assessment/files/2009/02/blackbox_a rticle.pdf.

Brookfield, Stephen D. (1986). Understanding and Facilitating Adult Learning. California: Jossey-Bass Inc.

Buchori, Mochtar. (2001). Pendidikan Antisipatoris. Yogyakarta: Penerbit Kanisius.

Dewey, John. (2009). Pendidikan Dasar Berbasis Pengalaman, terjemahan Irene V. Pontoh. Jakarta: PT. Indonesia Publishing.

Dimyati dan Mudjiono. (2006). Belajar dan Pembelajaran. Jakarta: PT. Rineka Cipta.

Djaali. (2008). Psikologi Pendidikan. Jakarta: Bumi Aksara.

Gage, N. L., dan David C. Berliner. (1984). Educational Psychology. Boston: Houghton Mifflin Company.

Johnson, Elaine B. (2009). Contextual Teaching \& Learning, terjemahan Ibnu Setiawan. Bandung: Mizan Learning Center.

Pidarta, Made. (2007). Landasan Kependidikan Stimulus IImu Pendidikan Bercorak Indo-nesia. Jakarta: PT. Rineka Cipta.

Prawiradilaga, Dewi Salma dan Eveline Siregar. (2008). Mozaik Teknologi Pendidikan. Jakarta: Kencana Prenada Media Group.

Ronney, Anne. (2009). The Story of Mathematics. London: Arcturus.

Rose, Colin dan Malcolm J. Nicholl. (1997). Accelerated Learning For The $21^{\text {ST }}$ Century. New York: Delacorte Press.

Santrock, John W. (2007). Educational Psychology, terjemahan Tri Wibowo B. S. Jakarta: Kencana Prenada Media Group.

Sekaran, Uma. (2006). Research Methods for Business buku 2, terjemahan Kwan Men Yon. Jakarta: Penerbit Salemba Empat. 
Shaffat, Idris. (2009). Optimized Learning Strategy Pendekatan Teoretis dan Praktis Meraih Keberhasilan Belajar. Jakarta: Prestasi Pustaka Publisher.

Sholeh, Munawar. (2005). Politik Pendidikan Membangun Sumber Daya Bangsa dengan Peningkatan Kualitas Pendidikan. Jakarta: Institute for Publik Education.

Stewart, James. (20010). Kalkulus Jilid 1, terjemahan I Nyoman Susila dan Hendra Gunawan. Jakarta: Gramedia.

Susetyo, Budi. (2008). "Penilaian Hasil Pembelajaran Kurikulum Tingkat Satuan Pendidikan (KTSP)." Hepimetro Files Wordpress, http://hepimetro. files.wordpress.com/2008/06/penilaian-pembelajaran-ktsp.pdf.

Walija. (2007). "Wacana Pengantar Setengah Abad FKIP UHAMKA Sajadah Panjang Perjuangan Pendidikan." Cakrawala Pendidikan, Jakarta: Uhamka Press.

Zainul, Asmawi dan Noehi Nasution. (2005). Penilaian Hasil Belajar. Jakarta: PAU-PPAI Universitas Terbuka. 